\title{
A PCR-mediated method for discrimination of Klebsiella oxytoca between closely related bacteria in environmental and clinical specimens
}

\author{
G. L. Kovtunovych, T. L. Lytvynenko, V. V. Negrutska, O. V. Lar, \\ N. V. Koltukova ${ }^{1}$, N. O. Kozyrovska \\ Institute of Molecular Biology and Genetics of the National Acaderny of Sciences \\ 150 'abolotnoho vul., Kyiv, 03143, Ukraine \\ ${ }^{1}$ Kyiv Research Institute of Epidemiology and Infection Diseases Academy of Medical Sciences \\ 4 Prolasiv Yar, Kyiv, 03038, Ukraine
}

\begin{abstract}
A specific detection method was developed to discriminate Klebsiella oxytoca between other species of the genus Klebsiella on the basis of PCR amplification of the unique DNA sequences within the polygalacturonase-encoding ( $p e h X$ ) gene. Four primers have been designed for performing $P C R s$ gaining amplicons of $282,344,45 I$ and $513 \mathrm{bp}$. The specificity of the test was verified by the lack of $P C R$ products in case of related $K$. pneumoniae, $K$. planticola, and polygalacturonate-degrading species of the genus Erwinia. The PCR-mediated test gives a rapid answer, concerning the presence of $K$. oxytoca in a sample, or in differentiating this bacterium from other species, such as $K$. pneumoniae, with which they can be confused. The diagnostic test can be used in ecological monitoring of $K$. oxytoca as well as in medical laboratories.
\end{abstract}

Introduction. The bacteria $K$. oxytoca and $K$. pneumoniae are controversial species of the genus $K l e b-$ siella. On the one hand, they are known as nitrogenfixing organisms beneficial in agriculture [1]. Besides, they are concerned with pioneer work on genetics $[2,3]$ and enzymology of nitrogen $\left(\mathrm{N}_{2}\right)$ fixation [4]. The nitrogen-fixing $K$. oxytoca strains have been isolated from the rhizosphere of rice [5], or from the interior of rice and sweet potato roots [6, 7 ]. $K$. pneumoniae has been isolated from the interior of maize roots [8]. At the same time, representatives of these two species are described as causal agents of human diseases [9].

The taxonomic position of $K$. oxytoca is still not clear, this bacterium is often in «the shadow» of $K$. pneumoniae as it was considered for a long time as a subspecies of the latter [10], and was separated only according to the DNA-DNA hybridization and phenotype characteristics [11]. According to the worldwide predominant Orskov's classification [10] $K$. oxytoca is an independent species of the genus,

(c) (i. L. KOVTUNOVYCH, T. LYTYYYNENKO, V. V. NEGRUTSKA, O. V. LAR, N. Y. KOLTUKOYA, N. O. KOZYROVSKA, 2003 however, within the classification of Cowan [9] which is also valid, there is no such a name. The lack of a consistent nomenclature results sometimes in mistakes in differentiation of the two species. Nitrogen-fixing isolates of Klebsiella, possessing distinguishing characteristics of $K$. oxytoca, have been designated as $K$. pneumoniae (for example, strain $K$. pneumoniae M5a1) [1]. Consequently, the name $K$. pneumoniae instead of $K$. oxytoca is probably used in many publications improperly. Nowadays, due to the rapid development of bioinformatics, DNA sequences of improperly named bacteria being deposited in public gene banks and spread quickly, determine the appearance of more errors.

Another reason for the misidentification of $K$. oxytoca is that detecting discriminative trait of $K$. oxytoca such as pectate degradation appears too labour-consuming to be taken into account in the identification process. The Biolog system and commercial biochemical tests (API 20E) designed for the Enterobacteriaceae identification are unreliable being used for the Klebsiella species differentiation. A new identification system designed on the basis of colony color and morphology on CHROMagar orientation 
A PCR-MEDLATED METHOD FOR DISCRIMINATION OF K. OXYTOCA

medium in combination with simple biochemical tests such as indole, lysine decarboxylase, and ornithine decarboxylase does not discriminate properly between $K$. oxytoca and $K$. pneumoniae as well [12].

Various DNA probes have been used in several hybridization and PCR procedures to distinguish $K$. oxytoca [13-18]. However, none of these techniques is completely satisfactory since the sequences used are not present exclusively in $K$. oxytoca (e. g. gyrA, parC, infB, rrs, and bla). This can lead to cross-reactions between the probe and DNA sequences from other species of the genus Klebsiella and from other enterobacteria resulting in a large number of false negatives or false positives.

The aim of this study was to devise a rapid and sensitive test for the discrimination between $K$. oxytoca and close relatives and detection of this bacterium in the environmental and clinical specimens. The idea was to exploit a pectate degradation capability of $K$. oxytoca, which distinguishes the bacterium from other species. More specifically, we used a unique sequence of the gene encoding the enzyme polygalacturonase that cleaves a polygalacturonic chain of demethoxylated pectin.

Materials and Methods. Bacteria are listed in Table 1.

DNA of nitrogen-fixing strain $K$. pneumonia 342 [8], $K$. pneumonia ZMVSY isolated from Wisconsin field, and clinic strain $K$. pneumonia MGH78578 were obtained from Dr. Eric Triplett (Wisconsin University).

Biochemical tests. Bacterial strains were considered as belonging to the genus Klebsiella on confident identification as $\ll K$. oxytoca or $K$. pneumoniae» after biochemical key tests such as indole (positive for $K$. oxytoca, negative for $K$. pneumoniae), melezitose (positive for some strains of $K$. oxytoca, negative for $K$. pneumoniae), gas production from lactose at $44.5{ }^{\circ} \mathrm{C}$ (positive for $K$. pneumoniae, negative for $K$. oxytoca), growth at $10^{\circ} \mathrm{C}$ (positive for $K$. oxytoca, negative for $K$. pneumoniae) [19]. The degradation of pectate [20] was used to analyze collection strains along with type ones. The cultures were spotted on pectate-containing semisolid PEC-SSA medium, and pectolytic ones exhibited indenting the agar.

$P C R$ and primer design. In this study, the tests were carried out by using lysed cells of approximately $1.0 \cdot 10^{7-8} \mathrm{cfu} / \mathrm{ml}$ in PCR mixtures with annealing temperature of $58{ }^{\circ} \mathrm{C}$ and $\mathrm{MgCl}_{2}$ concentration of $2.5 \mathrm{mM}$. The primer sequences PEH-A (5'-ggactacgccgtctatcgtcaag- $\left.3^{\prime}\right)$, PEH-B (5'-aatatccagggtcatatcgctgtg-3'), PEH-C (5'-gatacggagtatgccttacggtg $\left.-3^{\prime}\right)$, PEHD $\left(5^{\prime}\right.$-tagcctttatcaagcggatactgg- $\left.3^{\prime}\right)$ were chosen in the coding part of the gene. The primer and available

Table I

Bacterial strains used in experiments Bacterial Strains

\begin{tabular}{c|c}
\hline Bacterial Strains & Source \\
\hline
\end{tabular}

K. oxytoca $\mathrm{VN} 13$

K. oxytoca ATCC 13183

K. planticola ATCC 33531

$K$ pneumoniae ATCC 13183

$K$ pneumoniae CDC 50231

K. pneumoniae M5al

E. carotovora subsp. carotovora 8982

E. carotovora subsp. atroceptica 9027

E. chrysanthemi 8183

E. coli JM109

Klebsiella sp. 030039, 30041, 030042, 030044

K. pneumoniae NCTC* 5054

(K1), NCTC 5055 (K2), NCTC 9128 (K8), NCTC 9130 (K10),

NCTC 9131 (K11), NCTC 9132

(K12), NCTC 9136 (K16),

NCTC 9138 (K18), NCTC 9141

(K21), NCTC 9148 (K28),

NCTC 9150 (K30), NCTC 9157

(K37), NCTC 9161 (K41),

NCTC 9175 (K55), NCTC 9186

(K66), PZH** (K69), PZH

(K75), PZH (K76), PZH (K79)

${ }^{*}$ National Collection of Typical Cultures (London, UK); ${ }^{* *}$ Panstwowi Zaklad Hygieny (Institute of Hygiene, Warsaw, Poland).

sequences were compared according to the Blast $\mathrm{N}$ program of the Blast service at NCBI and FASTA one of the EMBO network services. Priming oligonucleotides were synthesised at the Institute of Bioorganic Chemistry of RAN (Russian Federation).

Results and Discussion Earlier the pehX gene of $K$. oxytoca VN13 has been cloned and sequenced (accession No AY06648) [21]. The sequence was compared with the other peh gene sequences available in GenBank, and the comparison did not display essential homology in the DNA sequences of pectinolytic bacteria. However, alignment of the encoded amino acids revealed 52-71\% homology with the Yersinia enterocolitica, E. chrysanthemi, and Ralstonia solanacearum exopolygalacturonases.

PCR-mediated method for detection of $K$. oxytoca. Our approach utilizes the PCR-mediated technique that allows determination of a specific gene in a living organism or a sample. The genetic marker 
pehX having been identified, permits the specific detection of $K$. oxytoca in any sample and discrimination of the bacterium from related strains. The se1 of strains, such as type strains of the genus Klebsiella ( $K$. oxytoca ATCC $13183, K$. planticola ATCC 33531 and $K$. pneumoniae ATCC 13883), well characterized strains $K$. pneumoniae $\mathrm{M} 5 \mathrm{al}$ and $K$. oxytoca VN13 $[1,6]$, as well as strains of the genus Erwinia, and E. coli JM109 analyzed previously by the method of pectate degradation, were used in experiments to verify specificity of the primers designed. All strains of Erwinia sank into the medium, as well as the $K$. oxytoca strains and $K$. pneumoniae M5al (Fig. 1). Other strains of Klebsiella grew but did not indent the medium. The $K$. oxytoca VN13 and $K$. oxylece ATCC 13183 sirains produced the 344 and 513 bp amplicons in PCR with a pair of primers, PEH-C, D, and PEH-A, D (Fig. 2, $A, B$ ). The $K$.

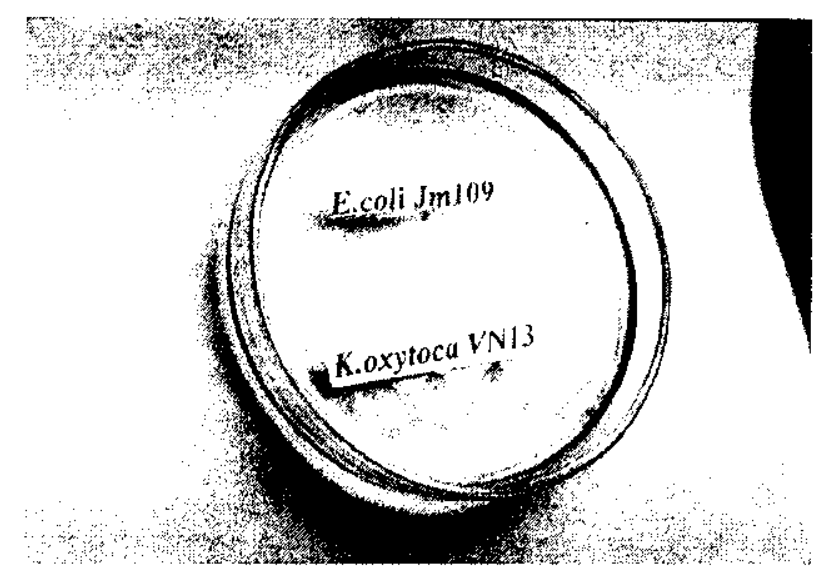

Fig. 1. Capability of Klebsiella oxytoca to indent a polygalacturonate semisolid agar as evidence for pectinase production pneumoniae ATCC 13883, E. carotovora subsp. carotovora, E. carotovora subsp. atroceptica, E. chrysanthemi, $K$. planticola ATCC 33531 and $E$. coli JM109 were negative in the PCR tests. The nitrogenfixing strain of $K$. pneumoniae M5al possessing characteristics of $K$. oxytoca, also generatcd specific amplicons of 344 and 513 bp (Fig. 2, C). DNA of diazotrophic bacterium $K$. pneumoniae 342 , correctly identified by molecular methods [8], was used as a reference in experiments to detect the pehX specific sequence in bacterial DNA. The primers designed for the pehX gene did not anneal to DNAs of $K$. pneumoniae $342, K$. pneumoniae ZMVSY and the clinical isolate $K$. pnetumoniae MGH78578.

Amplification of the unique DNA fragments in the PCR test revaled high level of specificity of the primers designed for the pehX gene. The negative results in $E$. carotovora and $E$. chrysanthemi strains were expected because there was practically no homology between the polygalacturonase-encoding gene of $K$. oxytoca and analogous genes of Erwinia [21]. The absence of amplicons in $K$. pneumoniae, $K$. planticola and $E$. coli JM109 can be explained by the absence of specific gene encoding the hydrolytic enzyme.

The method presented can be used for the detection of specific target bacteria in a complex sample mixture. The latter may contain a variety of components including non-target or background microorganisms. The method proceeds by first culturing the complex sample mixture in a non-selective growth medium followed by the PCR-mediated detection of a target bacterial DNA. The target DNA is detected via a DNA amplification protocol with a primer pair selected to amplify a specific portion of the target bacterial DNA. A control DNA is amplified in parallel with the target bacterial DNA. The control DNA is

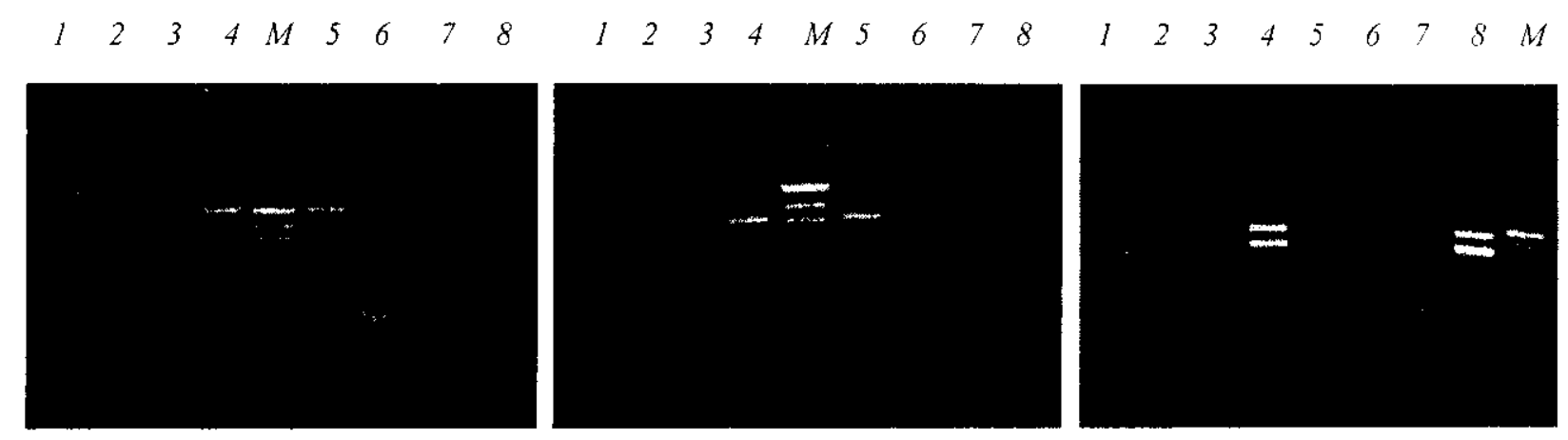

Fig. 2. Specific 513-bp $(A), 344-\mathrm{bp}(B), 451$ and 344-bp $(C)$ the peh gene fragments generated with $\mathrm{PCR}_{\mathrm{s}}(A, B: I-E$. coli JMl09; $2-$ $K$. pneumoniae ATCC $13883 ; 3-K$ planticola ATCC $33531 ; 4--K$ oxytoca VN13; $M-p U C 19 / H p a I I$ (marker); $5-K$. oxytoca ATCC $13183 ; 6-E$. carotovora subsp. carotovora $8982 ; 7-E$. carotovora subsp. atroceptica $9027 ; 8-E$. chrysanthemi $8183 ;$ C: $1-K$. pneumoniae PZH (K79); $2-K$ pneumoniae NCTC 9130 (K10); $3-K$ pneumoniae NCTC 9138 (K18); $4-K$ pneumoniae M5al; $5-$ $K$. pneumoniae ZMVSY; $6-K$. pneumoniae MGH78578; $7-K$. pneumoniae $342 ; 8-K$. pneumoniae NCTC 9186 (K66); $M-$ pUC $19 /$ HpalI (marker)) 
Table 2

Differentiation of Klebsiella spp. by biochemical tests

\begin{tabular}{|c|c|c|c|c|c|c|c|}
\hline \multirow{2}{*}{ Strain } & \multicolumn{7}{|c|}{ Trait } \\
\hline & Growth at $10^{\circ} \mathrm{C}$ & D-Melezitose & $\begin{array}{l}\text { Gas production from } \\
\text { lactose at } 44.5^{\circ} \mathrm{C}\end{array}$ & Indole production & Peclale & degradation & $\begin{array}{c}\text { Presence of a pehX } \\
\text { sequence }\end{array}$ \\
\hline K41 & + & + & 一 & + & & + & + \\
\hline K66 & + & + & - & + & & + & + \\
\hline K69 & + & - & - & + & & + & + \\
\hline $\mathrm{K} 75$ & + & + & - & + & & + & + \\
\hline K76 & + & + & - & + & & + & + \\
\hline K79 & + & + & + & + & & + & + \\
\hline $\mathrm{K} 10$ & - & - & + & - & & - & - \\
\hline $\mathrm{K} 21$ & - & - & + & - & & - & - \\
\hline K28 & - & - & + & - & & - & - \\
\hline $\mathrm{K} 30$ & - & - & + & - & & - & - \\
\hline K37 & - & - & + & - & & - & - \\
\hline K55 & 一 & - & + & - & & - & - \\
\hline $\begin{array}{l}K \text { pneumoniae } \\
\text { ATCC } 13883\end{array}$ & - & - & + & - & & - & - \\
\hline $\begin{array}{l}\text { K. oxytoca } \\
\text { ATCC } 13183\end{array}$ & + & + & - & + & & + & + \\
\hline K. oxytoca VN13 & + & - & - & + & & + & + \\
\hline
\end{tabular}

specifically designed to be amplified with the primers that are identical to the primers used in the amplification of the target genomic DNA. Use of this control validates the amplification reaction. Detection of the amplified target DNA and the control is accomplished by gel electrophoresis.

Screening collection of Klebsiella by a molecular method. A set of bacterial strains of the genus Klebsiella, deposited in the collection of Kyiv Research Institute of Epidemiology and Infection Diseases, both 1ype strains gathered from international collections and clinical isolates have been screened for the availability of the $p e h X$ gene. Five strains, deposited as $K$. pneumoniae (type strains K41, K66, K69, $\mathrm{K} 75$, K76), generated specific $K$. oxytoca amplicons with the primers PEH-A, B and PEH-C, D (see Fig. $2, C)$. DNA of $K$. pneumoniae $\mathrm{PZH}(\mathrm{K} 79)$ did give a 344 bp fragment, but did not give a 451 bp one which may be explained either by some deletion in the gene, or by a lack of homology between strains VN13 and $\mathrm{PZH}$ (K79) within sites of the primers PEH-A and $\mathrm{PEH}-\mathrm{B}$ recognition.

Identification of $K$. oxytoca or $K$. pneumoniae by biochemical tests. Six $\mathrm{Peh}^{+}$strains were examined by the biochemical key tests listed above that differentiate $K$. oxytoca from $K$. pneumoniae. In parallel six type strains of $K$. pneumoniae $(\mathrm{K} 10, \mathrm{~K} 21, \mathrm{~K} 28, \mathrm{~K} 30$,
K37, K55) that did not possess the pehX-specific sequence in their genomes were included in biochemical testing. The results of these tests correlated with the data of the peh DNA amplification and confirmed the taxonomic positions of six strains previously identified by molecular methods as $K$. oxytoca and six strains identified as $K$. pneumoniae (Table 2). This means that six type strains of $K$. pneumoniae deposited in international collections were identified earlier according to an outdated taxonomic system.

Conclusions. The rapid and sensitive PCR test for the discrimination of $K$. oxytoca between closely related bacteria and detection of this bacterium in environmental and clinical samples has been elaborated. The test is based on the recognition of unique DNA sequence within the gene encoding the polygalacturonase that cleaves a polygalacturonic chain of demethoxylated pectin. The use of different pairs of primers specific to the pehX gene helps to avoid mistakes in differentiation of $K$. oxytoca. The diagnostic test gives a rapid answer, regarding the presence of $K$. oxytoca in a sample, or in differentiating this bacterium from some other bacteria, such as $K$. pneumoniae, with which they can be confused. The specific PCR test overcomes the handicap of timeconsuming microbiological and biochemical methods 
and can be used for ecological monitoring $K$. oxytoca and in medical laboratories.

Acknowledgements. We are grateful to Eric Triplett (Wisconsin University) for providing the $K$. pneumoniae DNA and to Mike Merrik (John Innes Centre) for critical reading of the manuscript.

Г. Л. Ковтунович, Т. Л. Литвиненко, В. В. Негруцька,

О. В. Лар, Н. В. Колтукова, Н. В. Козировська

ПЛР-опосередкований метод визначення Klebsiella oxytoca серед близьких бактерій у природних та медичних зразках

\section{Резюме}

На основі ПЛР-амлліфікацї унікальних послідовностей ДНК гена, що кодує ферменп полігалактуроназу (реһX), розроблено cheиифічий метод для вирізнення бактерї $K$ oxytoca cереd iнuих бакmерій pody Klebsiella. Чотири пари праймерів створеto для отримання ампліконів 282, 344, $451 \mathrm{ma} 513 \mathrm{n} . \mathrm{H}$. Специфічність тесту підтверджено відсутністю продуктів ПЛР у близьких бактерій $K$. pneumoniae, $K$. planticola ma видіs pody Erwinia, uо розктадають полігалактуронат. ПЛР-тест дозволяе ивидко визначити наявність $K$. охутоса у зразку або відрізнити ию бактерію від представників інщих видів, наприклад, від $K$. pneumoniaе, яка дуже схожа на неї. Діагностинний тест може бути використано в екологінному моніторингу $K$. охутоса, а також у медичних лабораторіях.

Г. Л. Ковтунович, Т. Л. Литвиненко, В. В. Негруцкая,

E. B. Лар, Н. В. Колтукова, Н. А. Козыровская

ГІЦР-опосредованный метод для определения Klebsiella oxytoca среди близких бактерий в природных и медицинских образцах

\section{Резюме}

На основе ПЦР-амплификации уникальних последовательностей ДНК гена, кодирующего фермент полигалактуроназу (реһX), разработан метод для выявления бактерии $K$. охутоса среди друсих бактерий рода Klebsiella. Четыре пары праймеров созданы для получения ампликонов размером 282, 344, 451 и 513 пар нуклеотидов. Специфичность теста подтверждена отсутствием продуктов ПцР у близких бактерий $K$ рпеиmoniae, $K$ planticola и видов рода Erwinia, разлагаюцих полигалактуронат. ПЦР-тест позволяет быстро определить нали'ие $K$. охутоса в образиах или отличить эту бактерию от представителей других видов, например, от $K$ pneumoniae, которая очень на нее похожа. Диагностический тест может быть использован в экологическом мониторинге $\mathrm{K}$. охуtoca, a также в медицинских лабораториях.

\section{REFERENCES}

1. Mahl M. C., Wilson P. W. Nitrogen fixation by members of the tribe Klebsiellae // J. Bacteriol.-1968.-89.-P. 1482 1487.

2. Dixon R. A., Postgate J. R. Transfer of nitrogen fixation genes by conjugation in Klebsiella pneumoniae // Nature.-1971... 234. -P. $47-48$.

3. Streicher S. L., Gurney E. G., Valentine R. C. Transduction of nitrogen fixation genes in Klebsiella pneumoniae // Proc. Nat. Acad. Sci. USA. $-1971 .-68 .-P .1174-1177$.

4. Eady R. R., Smit B. E., Cook K. A., Postgate J. R. Nitrogenase of Klebsiella pneumoniae. Purification and properties of the component proteins // Biochem. J. -1972.-128.P. 655-675.
5. Hirota $Y$., Fujii $T$., Sano $Y$., Iyana S. Nitrogen fixation in the rhizosphere of rice // Nature.-1978.-276.-P. 416-417.

6. Kozyrovska N., Alexeyev M., Kovtunovych G., Gunkovska N., Kordyum V. Survival of Klebsiella oxytoca VN13 engineered to bioluminescence on barley roots during plant vegetation // Microbial Releases.-1994.-2.-P. 262-265.

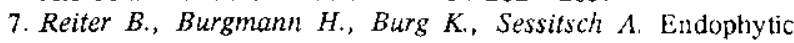
nifH gene diversity in African sweel potato // Can. J. Microbiol. -2003.-49.-P. 549-555.

8. Chelius $M . K$, Triplett $E$. W. Immunolocalization of dinitrogenase reductase produced by Klebsiella pneumoniae in association with Zea mays L. // Appl. Environ. Microbiol.2000.-66.-P. 783-787.

9. Podchun R., Ullmann U. Klebsiella spp. as nocosomial pathogens: epidemiology, laxonomy, typing methods, and pathogenicity factors $/ /$ Clin. Microbiol. Rev. -1998.-11-P. 589.

10. Orskov 1. Genus Klebsiella // Bergey's manual of determinative bacteriology / Eds R. E. Buchanau, N. E. Gibson.-Baltimore: Williams and Wilkins Co. publ, 1974.-P. 321-324.

11. Jain R., Radsak K., Mannheim W. Differentiation of the oxytocum group from Klebsiella by deoxyribonucleic aciddeoxyribonucleic acid hybridization // Int. J. Syst. Bacteriol.1974.-24.-P. 402-407.

12. Ohkusu $K$. Cost-effective and rapid presumptive identification of gram-negative bacilli in routine urine, pus, and stool cultures: evaluation of the use of CHROMagar orientation medium in conjunction with simple biochemical tests // J. Clin. Microbiol. - 2000.-38.-P. 4586-4592.

13. Hibbert-Rogers L. C., Heritage J., Gascoyne-Binzi D. M., Hawkey P. M., Todd N., Lewis I. J., Bailey C. Molecular epidemiology of ceftazidime resistant Enterobacteriaceae from patients on a paediatric oncology ward // J. Antimicrob. Chemother. $-1995 .-36$.-P. $65-82$.

14. Pat. USA WO $0123604-A 1929$ 05.04. Highly conserved genes and their use to generate probes and primers for detection of microorganisms / M. G. Bergeron, M. Boissinot, A. Huletsky, C. Nard, M. Ouellette, J. Picard, P. H. Roy.-Publ. 2001

15. Steffensen S. A., Poulsen A. B., Mortensen K. K. SperlingPetersen $H . U . E$. coli translation initiation factor IF2 - an extremely conserved protein. Comparative sequence analysis of the infB gene in clinical isolates of $E$. coli // FEBS Lett.1997.-419.-P. $281-284$.

16. Pat. USA WO 0123606 -A 14405.04 . Nucleic acid molecules for detecting bacteria and phylogenetic units of bacteria / R. Grabowski, K. Berghof.-Publ. 2001.

17. Anthony R. M., Brown T. J., French G. L. Rapid diagnosis of bacteremia by universal amplification of $23 \mathrm{~S}$ ribosomal DNA followed by hybridization to an oligonucleotide array // J. Clin. Microbiol. $-2000 .-38 .-P .781-788$.

18. Brisse S., Verhoef J. Phylogenetic diversity of Klebsiella pneumoniae and Klebsiella oxytoca clinical isolates revealed by randomly amplified polymorphic DNA, gyrA and parC genes sequencing and automated ribotyping // Int. J. Syst. Evol. Microbiol.-2001.-51.-P. 915-924.

19. Monnet D., Freney $J$. Method for differentiating Klebsiella planticola and Klebsiella terrigena from other Klebsiella species // J. Clin. Microbiol.-1994. $-32 .-P .1121-1122$.

20. Starr M. P., Chatterjee A. K. Starr P. B., Buhanan G. E. Enzymatic degradation of polygalacturonic acid by Yersinia and Klebsiella species in relation to clinical laboratory procedures // J. Clin. Microbiol.-1977.-6.-P. 379-386.

21. Kovtunovych G., Lar O., Kozyrovska N. Cloning and structurat analysis of the Klebsiella oxytoca VN13 peh gene // Biopolymery i klityna.-2000.-16.-P. 356-363. 